\title{
Exploring wealth-related inequalities in maternal and child health coverage in Latin America and the Caribbean
}

\author{
Manuel Colomé-Hidalgo ${ }^{1 *}$, Juan Donado Campos $^{2}$ and Ángel Gil de Miguel ${ }^{1}$
}

\begin{abstract}
Background: Maternal and child health have shown important advances in the world in recent years. However, national averages indicators hide large inequalities in access and quality of care in population subgroups. We explore wealth-related inequalities affecting health coverage and interventions in reproductive, maternal, newborn, and child health in Latin America and the Caribbean.

Methods: We analyzed representative national surveys from 15 countries conducted between 2001 and 2016. We estimated maternal-child health coverage gaps using the Composite Coverage Index - a weighted average of interventions that include family planning, maternal and newborn care, immunizations, and treatment of sick children. We measured absolute and relative inequality to assess gaps by wealth quintile. Pearson's correlation coefficient was used to test the association between the coverage gap and population attributable risk.

Results: The Composite Coverage Index showed patterns of inequality favoring the wealthiest subgroups. In eight countries the national coverage was higher than the global median (78.4\%; $95 \% \mathrm{Cl}$ : 73.1-83.6) and increased significantly as inequality decreased (Pearson $r=0.9 ; p<0.01$ ).

Conclusions: There are substantial inequalities between socioeconomic groups. Reducing inequalities will improve coverage indicators for women and children. Additional health policies, programs, and practices are required to promote equity.
\end{abstract}

Keywords: Maternal and child health, Health inequalities, Socioeconomic factors, Latin America, Caribbean region

\section{Background}

Reproductive, Maternal, Newborn, and Child Health (RMNCH) has been a global health policy priority for the past decade [1]. The Millennium Development Goals (MDGs) contributed enormously to the health of women and children, managing to reduce maternal and under- 5 years' old mortality and improved other indicators such as access to contraceptives, skilled attendance at childbirth, and measles vaccination [2]. Despite the progress,

\footnotetext{
* Correspondence: manuel.colome@intec.edu.do

${ }^{1}$ Instituto Tecnológico de Santo Domingo, Universidad Rey Juan Carlos, Madrid, Spain

Full list of author information is available at the end of the article
}

most regions did not reach the proposed goals, showing uneven progress that has left gaps between countries, especially in Latin America and the Caribbean (ALC) $[3,4]$.

The 2030 agenda for Sustainable Development Goals (SDGs) broadens the scope of the MDGs, assuming the commitment to leave no one behind. The SDG-3.8 promotes universal health coverage in terms of access to quality healthcare services, medicines, and vaccines for all [5]. More granular analysis of indicators can show whether all subgroups of the population will benefit from national progress or not [6]. Monitoring inequalities allow identifying vulnerable groups and prioritizing

(c) The Author(s). 2021 Open Access This article is licensed under a Creative Commons Attribution 4.0 International License, which permits use, sharing, adaptation, distribution and reproduction in any medium or format, as long as you give appropriate credit to the original author(s) and the source, provide a link to the Creative Commons licence, and indicate if changes were made. The images or other third party material in this article are included in the article's Creative Commons licence, unless indicated otherwise in a credit line to the material. If material is not included in the article's Creative Commons licence and your intended use is not permitted by statutory regulation or exceeds the permitted use, you will need to obtain permission directly from the copyright holder. To view a copy of this licence, visit http://creativecommons.org/licenses/by/4.0/ The Creative Commons Public Domain Dedication waiver (http://creativecommons.org/publicdomain/zero/1.0/) applies to the data made available in this article, unless otherwise stated in a credit line to the data. 
interventions in those who need it the most, thus promoting health coverage through equity [7]. We analyzed the Composite Coverage Index (CCI) as an indicator of universal healthcare coverage gaps in women and children. The index combines preventive and curative interventions throughout the continuum of care, family planning, maternal and newborn care, immunization, and treatment of sick children and has been used to monitor SDGs progress $[8,9]$.

Previous studies have emphasized the wealth-related inequalities between countries implementing the CCI, but only a few have focused on the LAC situation [1012]. Therefore, the scope of health interventions and the level of improvement needed to narrow the gap needs to be adequately defined. This study explores wealthrelated inequalities in $\mathrm{RMNCH}$ care coverage and its impact on reducing the gap in the LAC countries between 2001 and 2016.

\section{Methods}

This was a descriptive study based on secondary RMNC $\mathrm{H}$ coverage data obtained from the World Health Organization (WHO) Health Equity Assessment Toolkit (HEAT) software version 3.1 [13]. HEAT performs health inequality measures calculations from the WHO Health Equity Monitor Database [14]. The database includes data from Demographic Health Surveys (DHS), Multiple Indicators Cluster Survey (MICS) and Reproductive Health Surveys (RHS). The surveys carried out national representative and standardized interviews with women $15-49$ years old. We included 15 of 22 countries with surveys conducted between 2001 and 2016 based on the availability of recent data on the Composite Coverage Index and wealth quintile.

The CCI is a weighted score based on aggregate estimates of eight essential interventions for the continuum of care for women and children, from before pregnancy to delivery, the immediate postnatal period, and childhood $[7,15]$. The index is calculated using the formula:

$$
C C I=\frac{1}{4}\left(D F P S+\frac{A N C 4+S B A}{2}+\frac{B C G+2 \mathrm{DPT} 3+\mathrm{MCV}}{4}+\frac{O R S+C P N M}{2}\right)
$$

where DFPS = satisfied demand for modern family planning methods; $\mathrm{ANC4}=$ prenatal care (at least four visits); $\mathrm{SBA}=$ deliveries attended by qualified personnel; $\mathrm{BCG}=$ one dose of Bacillus Calmette-Guérin vaccine; DPT3 = three or more doses of diphtheria-tetanuspertussis vaccine; $\mathrm{MCV}=$ at least one dose of measles vaccine; ORS = children with diarrhea receiving oral rehydration therapy and continuous feeding; NSCLC = children with pneumonia symptoms taken to a health center [16].

We calculated CCI's, mean, median, interquartile range and standard deviation for the region. We analyzed socioeconomic inequality using the wealth index, which is an estimate based on the ownership of selected assets, housing construction materials, and access to basic services. The details of wealth index estimation have been previously described [17]. Households are classified from the poorest $(\mathrm{Q} 1)$ to the richest $(\mathrm{Q} 5)$ [18].

To compare patterns of inequality between and within countries, first, we calculated the coverage difference to show the magnitude of absolute inequality (Q5-Q1); second, the coverage ratio to show proportional differences between groups (Q5 / Q1) and third, the ratio of differences between coverages in lower (Q1-Q2) and higher quintiles (Q4-Q5). We calculated the relative concentration index and slope index to describe inequalities in all subgroups. Finally, we use population attributable risk (PAR) to show the possible improvement if the general population hypothetically had the same coverage level as the wealthiest quintile (CCI-Q5). We estimated the PAR percentage (PAR\%) to show the proportion of improvement in national coverage if socioeconomic inequality would have been eliminated (PAR / CCI * 100) [19]. We used Pearson correlation to measure the degree of relationship between the CCI and the PAR\%. The analyses were performed using Microsoft Excel and HEAT Plus software.

\section{Results}

Supplementary Table 1 shows the average coverage by wealth quintile for each of the maternal and child health interventions. The coverage gap tended to be smaller as the income level improved. National coverage was greater than $78 \%$ in all interventions except family planning and treatment of sick children. The greatest inequality occurred in skilled attendance at birth and prenatal care, where the difference between the wealthiest and the poorest was 26.4 and $17.3 \%$, respectively. The difference was relatively smaller in the immunization indicators, where the absolute inequality was more pronounced in the coverage of DTP3 than in BCG and measles. The difference ratio was well over 1.0 for most of the interventions, showing a wide gap to the detriment of the poorest quintile, except in the vaccination against measles.

Table 1 shows the coverage gaps and inequalities by wealth quintiles for each country. The national median was $78.4 \%$ (Range: $49.8 \%$ [Haiti] - 86.6\% [El Salvador]) and from $71 \%$ for the poorest quintiles and $82 \%$ for the wealthiest. In three countries - Haiti, Bolivia, and Guatemala - wide differences ( $>21$ percentage points) were observed between the wealthiest and poorest quintiles. Guyana, Costa Rica, and Paraguay were the only countries with the lowest coverage in the wealthiest quintile. Belize, Costa Rica, the Dominican Republic, El 
Table 1 Inequality gaps in CCI by wealth quintile, LAC 2001-2016

\begin{tabular}{|c|c|c|c|c|c|c|c|c|c|c|c|c|c|c|c|}
\hline \multirow[t]{2}{*}{ Countries } & \multicolumn{8}{|c|}{ Coverage (\%) [Cl 95\%] } & \multirow[b]{2}{*}{ D } & \multirow[b]{2}{*}{$\mathbf{R}$} & \multirow[b]{2}{*}{ RD } & \multicolumn{4}{|c|}{ Equity measures } \\
\hline & Survey & Year & National & Q1 & Q2 & Q3 & Q4 & Q5 & & & & SII & $\mathrm{RCl}$ & PAR & PAR $\%$ \\
\hline Belize & MICS & 2015 & $\begin{array}{l}77.3 \\
{[75.4-} \\
79.1]\end{array}$ & $\begin{array}{l}71.2 \\
{[69.1-} \\
73.2]\end{array}$ & $\begin{array}{l}77.1 \\
{[69.0-} \\
73.1]\end{array}$ & $\begin{array}{l}79.8 \\
{[77.9-} \\
81.6]\end{array}$ & $\begin{array}{l}77.6 \\
{[75.7-} \\
79.4]\end{array}$ & $\begin{array}{l}81.0 \\
{[79.2-} \\
82.7]\end{array}$ & $\begin{array}{l}9.80 \\
{[8.4-} \\
11.1]\end{array}$ & $\begin{array}{l}1.1 \\
{[0.6-} \\
1.5]\end{array}$ & 1.7 & $\begin{array}{l}10.0 \\
{[8.6-} \\
11.3]\end{array}$ & $\begin{array}{l}2.0 \\
{[1.3-} \\
2.6]\end{array}$ & $\begin{array}{l}3.7 \\
{[2.7-} \\
4.6]\end{array}$ & 5 \\
\hline Bolivia & DHS & 2008 & $\begin{array}{l}61.7 \\
{[60.5-} \\
62.8]\end{array}$ & $\begin{array}{l}49.4 \\
{[48.2-} \\
50.5]\end{array}$ & $\begin{array}{l}58.0 \\
{[56.8-} \\
59.1]\end{array}$ & $\begin{array}{l}64.1 \\
{[62.9-} \\
65.2]\end{array}$ & $\begin{array}{l}68.8 \\
{[67.7-} \\
69.8]\end{array}$ & $\begin{array}{l}73.8 \\
{[72.7-} \\
74.8]\end{array}$ & $\begin{array}{l}24.4 \\
{[2.0-} \\
2.7]\end{array}$ & $\begin{array}{l}1.5 \\
{[1.2-} \\
1.7]\end{array}$ & 1.7 & $\begin{array}{l}29.4 \\
{[28.3-} \\
30.4]\end{array}$ & $\begin{array}{l}7.6 \\
{[6.9-} \\
8.2]\end{array}$ & $\begin{array}{l}11.0 \\
{[10.4-} \\
11.5]\end{array}$ & 18 \\
\hline Colombia & DHS & 2010 & $\begin{array}{l}81.1 \\
{[80.5-} \\
81.6]\end{array}$ & $\begin{array}{l}73.8 \\
{[73.1-} \\
74.4]\end{array}$ & $\begin{array}{l}81.9 \\
{[81.3-} \\
82.4]\end{array}$ & $\begin{array}{l}84.0 \\
{[83.4-} \\
84.5]\end{array}$ & $\begin{array}{l}84.4 \\
{[83.8-} \\
84.9]\end{array}$ & $\begin{array}{l}84.7 \\
{[84.1-} \\
85.2]\end{array}$ & $\begin{array}{l}10.9 \\
{[10.4-} \\
11.3]\end{array}$ & $\begin{array}{l}1.1 \\
{[0.9-} \\
1.2]\end{array}$ & 27.0 & $\begin{array}{l}12.2 \\
{[11.7-} \\
12.6]\end{array}$ & $\begin{array}{l}2.4 \\
{[2.1-} \\
2.6]\end{array}$ & $\begin{array}{l}2.9 \\
{[2.7-} \\
3.2]\end{array}$ & 4 \\
\hline Costa Rica & MICS & 2011 & $\begin{array}{l}84.7 \\
{[83.0-} \\
86.3]\end{array}$ & $\begin{array}{l}81.4 \\
{[79.6-} \\
83.1]\end{array}$ & $\begin{array}{l}88.2 \\
{[86.7-} \\
89.6]\end{array}$ & $\begin{array}{l}80.4 \\
{[78.6-} \\
82.1]\end{array}$ & $\begin{array}{l}86.0 \\
{[84.4-} \\
87.5]\end{array}$ & $\begin{array}{l}85.1 \\
{[83.5-} \\
86.6]\end{array}$ & $\begin{array}{l}3.7 \\
{[2.8-} \\
4.5]\end{array}$ & $\begin{array}{l}1.0 \\
{[0.5-} \\
1.4]\end{array}$ & -7.6 & $\begin{array}{l}2.6 \\
{[1.8-} \\
3.3]\end{array}$ & $\begin{array}{l}0.5 \\
{[0.1-} \\
0.8]\end{array}$ & $\begin{array}{l}0.9 \\
{[0.1-} \\
0.7]\end{array}$ & 1 \\
\hline $\begin{array}{l}\text { Dominican } \\
\text { Republic }\end{array}$ & MICS & 2014 & $\begin{array}{l}78.4 \\
{[77.6-} \\
79.1]\end{array}$ & $\begin{array}{l}74.3 \\
{[73.5-} \\
75.0]\end{array}$ & $\begin{array}{l}78.2 \\
{[77.4-} \\
78.9]\end{array}$ & $\begin{array}{l}80.5 \\
{[79.8-} \\
81.1]\end{array}$ & $\begin{array}{l}78.3 \\
{[77.5-} \\
79.0]\end{array}$ & $\begin{array}{l}82.2 \\
{[81.5-} \\
82.8]\end{array}$ & $\begin{array}{l}7.9 \\
{[7.4-} \\
8.3]\end{array}$ & $\begin{array}{l}1.1 \\
{[0.9-} \\
1.2]\end{array}$ & 1.0 & $\begin{array}{l}8.0 \\
{[7.4-} \\
8.5]\end{array}$ & $\begin{array}{l}1.6 \\
{[1.3-} \\
1.8]\end{array}$ & $\begin{array}{l}3.5 \\
{[3.2-} \\
3.8]\end{array}$ & 4 \\
\hline El Salvador & MICS & 2014 & $\begin{array}{l}86.6 \\
{[85.69-} \\
87.51]\end{array}$ & $\begin{array}{l}84.1 \\
{[83.1-} \\
85.0]\end{array}$ & $\begin{array}{l}86.5 \\
{[85.5-} \\
87.4]\end{array}$ & $\begin{array}{l}87.5 \\
{[86.6-} \\
88.3]\end{array}$ & $\begin{array}{l}86.5 \\
{[85.5-} \\
87.4]\end{array}$ & $\begin{array}{l}89.1 \\
{[88.2-} \\
89.9]\end{array}$ & $\begin{array}{l}5.0 \\
{[4.4-} \\
5.5]\end{array}$ & $\begin{array}{l}1.1 \\
{[0.8-} \\
1.3]\end{array}$ & 0.9 & $\begin{array}{l}5.0 \\
{[4.4-} \\
5.5]\end{array}$ & $\begin{array}{l}0.9 \\
{[0.6-} \\
1.1]\end{array}$ & $\begin{array}{l}2.4 \\
{[1.9-} \\
2.8]\end{array}$ & 3 \\
\hline Guatemala & DHS & 2014 & $\begin{array}{l}68.9 \\
{[68.0-} \\
69.7]\end{array}$ & $\begin{array}{l}58.7 \\
{[57.7-} \\
59.6]\end{array}$ & $\begin{array}{l}64.2 \\
{[63.2-} \\
65.1]\end{array}$ & $\begin{array}{l}70.7 \\
{[69.8-} \\
71.5]\end{array}$ & $\begin{array}{l}75.9 \\
{[75.0-} \\
76.7]\end{array}$ & $\begin{array}{l}80.1 \\
{[79.3-} \\
80.8]\end{array}$ & $\begin{array}{l}21.4 \\
{[20.6-} \\
22.1]\end{array}$ & $\begin{array}{l}1.4 \\
{[1.1-} \\
1.6]\end{array}$ & 1.3 & $\begin{array}{l}27.0 \\
{[26.1-} \\
27.8]\end{array}$ & $\begin{array}{l}6.2 \\
{[5.7-} \\
6.6]\end{array}$ & $\begin{array}{l}10.2 \\
{[9.8-} \\
10.6]\end{array}$ & 15 \\
\hline Guyana & MICS & 2014 & $\begin{array}{l}73.7 \\
{[71.8-} \\
75.5]\end{array}$ & $\begin{array}{l}70.6 \\
{[68.6-} \\
72.5]\end{array}$ & $\begin{array}{l}73.3 \\
{[71.4-} \\
75.1]\end{array}$ & $\begin{array}{l}71.6 \\
{[69.7-} \\
73.4]\end{array}$ & $\begin{array}{l}78.5 \\
{[76.7-} \\
80.2]\end{array}$ & $\begin{array}{l}72.7 \\
{[70.8-} \\
74.5]\end{array}$ & $\begin{array}{l}2.1 \\
{[1.5-} \\
2.7]\end{array}$ & $\begin{array}{l}1.0 \\
{[0.5-} \\
1.4]\end{array}$ & -0.5 & $\begin{array}{l}4.7 \\
{[3.8-} \\
5.5]\end{array}$ & $\begin{array}{l}1.0 \\
{[0.5-} \\
1.4]\end{array}$ & $\begin{array}{l}0[- \\
0.9-0.9]\end{array}$ & 0 \\
\hline Haiti & DHS & 2016 & $\begin{array}{l}49.8 \\
{[48.5-} \\
51.1]\end{array}$ & $\begin{array}{l}37.9 \\
{[36.6-} \\
39.1]\end{array}$ & $\begin{array}{l}43.8 \\
{[42.5-} \\
45.0]\end{array}$ & $\begin{array}{l}51.6 \\
{[50.3-} \\
52.9]\end{array}$ & $\begin{array}{l}58.3 \\
{[57.0-} \\
59.5]\end{array}$ & $\begin{array}{l}65.3 \\
{[64.0-} \\
66.5]\end{array}$ & $\begin{array}{l}27.4 \\
{[26.2-} \\
28.5]\end{array}$ & $\begin{array}{l}1.7 \\
{[1.3-} \\
2.0]\end{array}$ & 0.8 & $\begin{array}{l}34.0 \\
{[32.7-} \\
35.2]\end{array}$ & $\begin{array}{l}10.8 \\
{[9.9-} \\
11.6]\end{array}$ & $\begin{array}{l}13.9 \\
{[13.3-} \\
14.5]\end{array}$ & 28 \\
\hline Honduras & DHS & 2011 & $\begin{array}{l}79.7 \\
{[78.8-} \\
80.5]\end{array}$ & $\begin{array}{l}74.1 \\
{[73.2-} \\
74.9]\end{array}$ & $\begin{array}{l}78.8 \\
{[77.9-} \\
79.6]\end{array}$ & $\begin{array}{l}81.3 \\
{[80.5-} \\
82.1]\end{array}$ & $\begin{array}{l}82.2 \\
{[81.4-} \\
82.9]\end{array}$ & $\begin{array}{l}83.6 \\
{[82.8-} \\
84.3]\end{array}$ & $\begin{array}{l}9.5 \\
{[8.9-} \\
10.1]\end{array}$ & $\begin{array}{l}1.1 \\
{[0.8-} \\
1.3]\end{array}$ & 3.4 & $\begin{array}{l}11.2 \\
{[10.5-} \\
11.8]\end{array}$ & $\begin{array}{l}2.2 \\
{[1.9-} \\
2.5]\end{array}$ & $\begin{array}{l}3.6 \\
{[3.2-} \\
4.0]\end{array}$ & 5 \\
\hline Mexico & MICS & 2015 & $\begin{array}{l}81.3 \\
{[80.2-} \\
82.3]\end{array}$ & $\begin{array}{l}79.4 \\
{[78.3-} \\
80.4]\end{array}$ & $\begin{array}{l}78.8 \\
{[77.6-} \\
79.9]\end{array}$ & $\begin{array}{l}78.6 \\
{[77.4-} \\
79.7]\end{array}$ & $\begin{array}{l}85.4 \\
{[84.4-} \\
86.3]\end{array}$ & $\begin{array}{l}86.7 \\
{[85.7-} \\
87.6]\end{array}$ & $\begin{array}{l}7.3 \\
{[6.6-8]}\end{array}$ & $\begin{array}{l}1.1 \\
{[0.8-} \\
1.3]\end{array}$ & -0.5 & $\begin{array}{l}1.1 \\
{[0.8-} \\
1.3]\end{array}$ & $\begin{array}{l}2.1 \\
{[1.7-} \\
2.4]\end{array}$ & $\begin{array}{l}4.9 \\
{[4.4-} \\
5.4]\end{array}$ & 6 \\
\hline Nicaragua & DHS & 2001 & $\begin{array}{l}75.3 \\
{[74.1-} \\
76.4]\end{array}$ & $\begin{array}{l}63.6 \\
{[62.3-} \\
64.8]\end{array}$ & $\begin{array}{l}75.9 \\
{[74.7-} \\
77.0]\end{array}$ & $\begin{array}{l}79.2 \\
{[78.1-} \\
80.2]\end{array}$ & $\begin{array}{l}79.8 \\
{[78.7-} \\
80.8]\end{array}$ & $\begin{array}{l}82.2 \\
{[81.2-} \\
83.2]\end{array}$ & $\begin{array}{l}18.6 \\
{[17.5-} \\
19.6]\end{array}$ & $\begin{array}{l}1.3 \\
{[1-} \\
1.6]\end{array}$ & 5.1 & $\begin{array}{l}20.5 \\
{[19.4-} \\
21.5]\end{array}$ & $\begin{array}{l}4.3 \\
{[3.7-} \\
4.8]\end{array}$ & $\begin{array}{l}6.1 \\
{[5.5-} \\
6.6]\end{array}$ & 8 \\
\hline Panama & MICS & 2013 & $\begin{array}{l}79.0 \\
{[77.7-} \\
80.2]\end{array}$ & $\begin{array}{l}65.2 \\
{[63.7-} \\
66.6]\end{array}$ & $\begin{array}{l}83.8 \\
{[82.6-} \\
84.9]\end{array}$ & $\begin{array}{l}81.0 \\
{[79.7-} \\
82.2]\end{array}$ & $\begin{array}{l}89.0 \\
{[88.0-} \\
89.9]\end{array}$ & $\begin{array}{l}83.8 \\
{[82.6-} \\
84.9]\end{array}$ & $\begin{array}{l}18.6 \\
{[17.3-} \\
19.8]\end{array}$ & $\begin{array}{l}1.3 \\
{[0.9-} \\
1.6]\end{array}$ & -3.6 & $\begin{array}{l}21.2 \\
{[19.9-} \\
22.4]\end{array}$ & $\begin{array}{l}4.2 \\
{[3.5-} \\
4.8]\end{array}$ & $\begin{array}{l}3.2 \\
{[2.6-} \\
3.9]\end{array}$ & 4 \\
\hline Paraguay & MICS & 2016 & $\begin{array}{l}81.5 \\
{[80.1-} \\
82.8]\end{array}$ & $\begin{array}{l}78.9 \\
{[77.4-} \\
80.3]\end{array}$ & $\begin{array}{l}81.5 \\
{[80.1-} \\
82.8]\end{array}$ & $\begin{array}{l}83.3 \\
{[81.9-} \\
84.6]\end{array}$ & $\begin{array}{l}82.3 \\
{[80.9-} \\
83.6]\end{array}$ & $\begin{array}{l}82.8 \\
{[81.4-} \\
84.1]\end{array}$ & $\begin{array}{l}3.9 \\
{[3.2-} \\
4.5]\end{array}$ & $\begin{array}{l}1.0 \\
{[0.6-} \\
1.3]\end{array}$ & 5.2 & $\begin{array}{l}4.3 \\
{[3.5-} \\
5.0]\end{array}$ & $\begin{array}{l}0.8 \\
{[0.4-} \\
1.1]\end{array}$ & $\begin{array}{l}1.0 \\
{[0.4-} \\
1.7]\end{array}$ & 1 \\
\hline Peru & $\mathrm{DHS}$ & 2016 & $\begin{array}{l}74.3 \\
{[73.4-} \\
75.1]\end{array}$ & $\begin{array}{l}65.4 \\
{[64.5-} \\
66.2]\end{array}$ & $\begin{array}{l}74.2 \\
{[73.3-} \\
75.0]\end{array}$ & $\begin{array}{l}75.2 \\
{[74.4-} \\
76]\end{array}$ & $\begin{array}{l}79.0 \\
{[78.2-} \\
79.7]\end{array}$ & $\begin{array}{l}80.8 \\
{[80.0-} \\
81.5]\end{array}$ & $\begin{array}{l}15.4 \\
{[14.7-} \\
16.0]\end{array}$ & $\begin{array}{l}1.2 \\
{[1-} \\
1.4]\end{array}$ & 4.9 & $\begin{array}{l}17.8 \\
{[17.0-} \\
18.5]\end{array}$ & $\begin{array}{l}3.8 \\
{[3.4-} \\
4.1]\end{array}$ & $\begin{array}{l}5.9 \\
{[5.5-} \\
6.3]\end{array}$ & 8 \\
\hline Median & & & 78.4 & 71.2 & 78.2 & 79.8 & 79.8 & 82.2 & 9.8 & 1.1 & 1.3 & 11.2 & 2.2 & 3.6 & 4.5 \\
\hline Mean & & & 75.7 & 68.2 & 75.2 & 76.8 & 79.5 & 81.0 & 12.2 & 1.2 & 2.6 & 13.9 & 3.3 & 4.9 & 7.3 \\
\hline $\begin{array}{l}95 \% \mathrm{Cl} \text { for } \\
\text { the mean }\end{array}$ & & & $73.1-83.6$ & $\begin{array}{l}64.2- \\
78.1\end{array}$ & $\begin{array}{l}71.7- \\
84.6\end{array}$ & $\begin{array}{l}74.7- \\
84.8\end{array}$ & $\begin{array}{l}75.5- \\
84.0\end{array}$ & $\begin{array}{l}78.8- \\
85.5\end{array}$ & $\begin{array}{l}5.3- \\
14.2\end{array}$ & $\begin{array}{l}0.9- \\
1.2\end{array}$ & $\begin{array}{l}1.4- \\
6.8\end{array}$ & $\begin{array}{l}81.4- \\
196.6\end{array}$ & $\begin{array}{l}16.9- \\
49.0\end{array}$ & $2.7-7.1$ & $\begin{array}{l}3.1- \\
11.4\end{array}$ \\
\hline $\begin{array}{l}\text { Interquartile } \\
\text { range }\end{array}$ & & & 73.9-81.3 & $\begin{array}{l}51.7- \\
74.3\end{array}$ & $\begin{array}{l}73.5- \\
81.8\end{array}$ & $\begin{array}{l}72.5- \\
81.2\end{array}$ & $\begin{array}{l}77.8- \\
85.2\end{array}$ & $\begin{array}{l}80.3- \\
84.5\end{array}$ & $\begin{array}{l}5.6- \\
18.6\end{array}$ & $\begin{array}{l}1.1- \\
1.3\end{array}$ & $\begin{array}{l}-0.2- \\
4.5\end{array}$ & $\begin{array}{l}4.7- \\
21.2\end{array}$ & $1.0-4.3$ & $2.4-3.7$ & $\begin{array}{l}2.8- \\
5.3\end{array}$ \\
\hline $\begin{array}{l}\text { Standard } \\
\text { deviation }\end{array}$ & & & 9.2 & 12.6 & 11.3 & 8.8 & 7.5 & 5.9 & 7.8 & 0.2 & 7.3 & 10.4 & 2.9 & 3.9 & 7.5 \\
\hline
\end{tabular}


Salvador, Guyana, Honduras, Mexico, and Paraguay showed low levels of inequality, where the difference between the wealthiest and poorest quintiles was 10 percentage points or less. Haiti was the country with the highest level of relative inequality, with coverage in the wealthiest quintile that exceeds that of the poorest by a factor of 1.7. The ratio of differences between the lowest and highest quintiles was greater than 1.0 in nine countries, showing a predominant pattern of higher inequality where the wealthiest quintile had disproportionately less coverage than all the other quintiles, led by Colombia. Reducing wealth-related inequality had the potential to narrow the national gap between $1 \%$ (Costa Rica) and $27.9 \%$ (Haiti). If all countries could reach the median overall coverage for the wealthiest quintile, the gap would decrease by 3.6 percentage points $(95 \% \mathrm{CI}$ : 2.7-7.1).

LAC countries showed a pattern of marginal exclusion in maternal-child health coverage, highlighting the need to address interventions oriented to the most disadvantaged population and also a pattern of higher wealth-related inequality in $\mathrm{CCI}$ coverage to the detriment of the poorest quintile (Fig. 1-2). Figure 3 shows the relationship between the $\mathrm{CCI}$ gap and PAR\% in the study countries. It was observed that healthcare coverage increased significantly as inequality decreased (Pearson $\mathrm{r}=0.9 ; p<0.01$ ). To achieve equality in the distribution of $\mathrm{RMNCH}$ interventions, Haiti (27.9\%), Guatemala (14.8\%) and Bolivia $(17.8 \%)$ would need to make a greater effort to reduce the ICC gap at their respective levels.

\section{Discussion}

The LAC region has experienced a considerable improvement in maternal and child health post-2015 sustainable development agenda [7]. Despite the progress, it is currently considered the most unequal region in the world, which represents a major challenge for the SDGs [20].

We explore current wealth-related inequalities in $\mathrm{RMNCH}$ coverage in $15 \mathrm{LAC}$ countries. Our findings reveal important inequalities in maternal and child health interventions, pointing out that in some groups of the population women and children are lagging.

As shown in this study, essential preventive and curative interventions showed a monotonous pattern with lower levels in the poorest quintile. The inequality gap was greater in interventions that required a functional health system and recurrent interaction with healthcare personnel, except in immunizations. Although approximately $80 \%$ of the population benefited from the eight essential interventions, coverage of RMNCH interventions was lower than that in more than half of the poorest countries. Only Costa Rica and El Salvador reached this level in the poorest quintile. The difference between the wealthiest and the poorest was at least 9.8 percentage points in more than half of the countries. Haiti, Bolivia, Guatemala, Peru, and Nicaragua showed lower national coverage and absolute inequality above the regional median. Colombia showed greater inequality of coverage in the top quintiles despite not having a wide gap like other countries. These findings imply the need for health systems that prioritize adequate care to reduce the gaps in women and children from the poorest

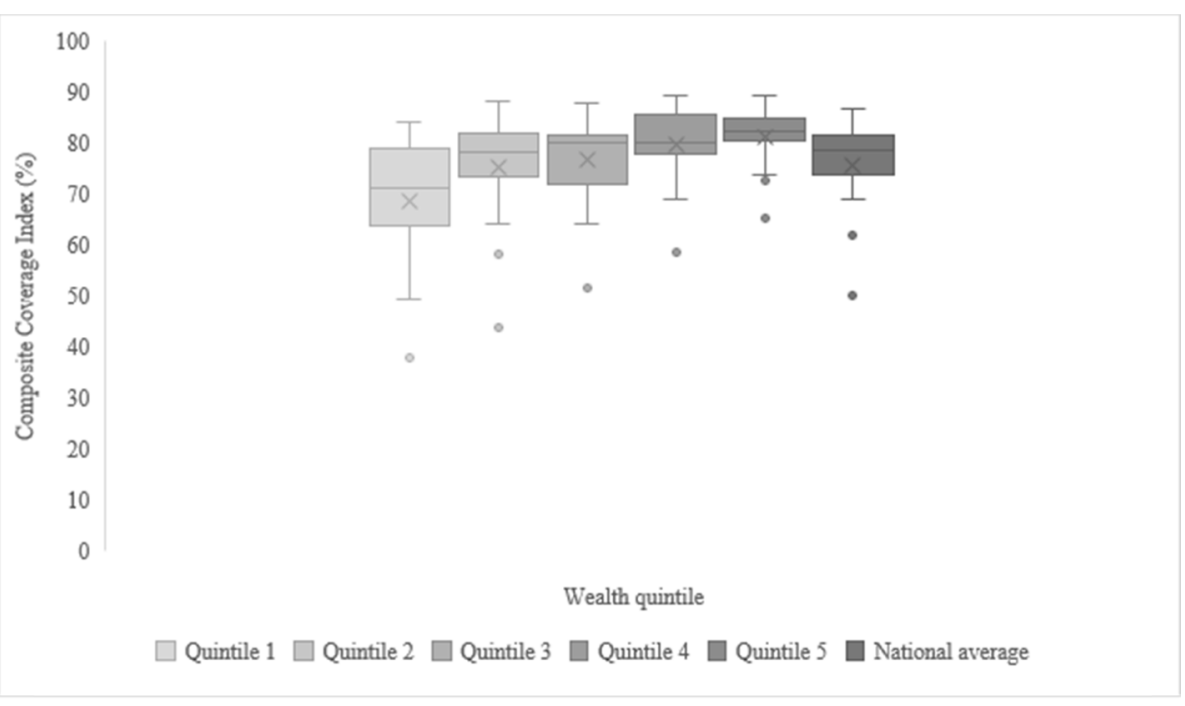

Source: Own elaboration based on study data.

Fig. 1 Latest situation of CCI coverage by economic status, LAC 2001-2016. Own elaboration based on study data. ${ }^{\text {a }}$ Dashed lines indicate the median 


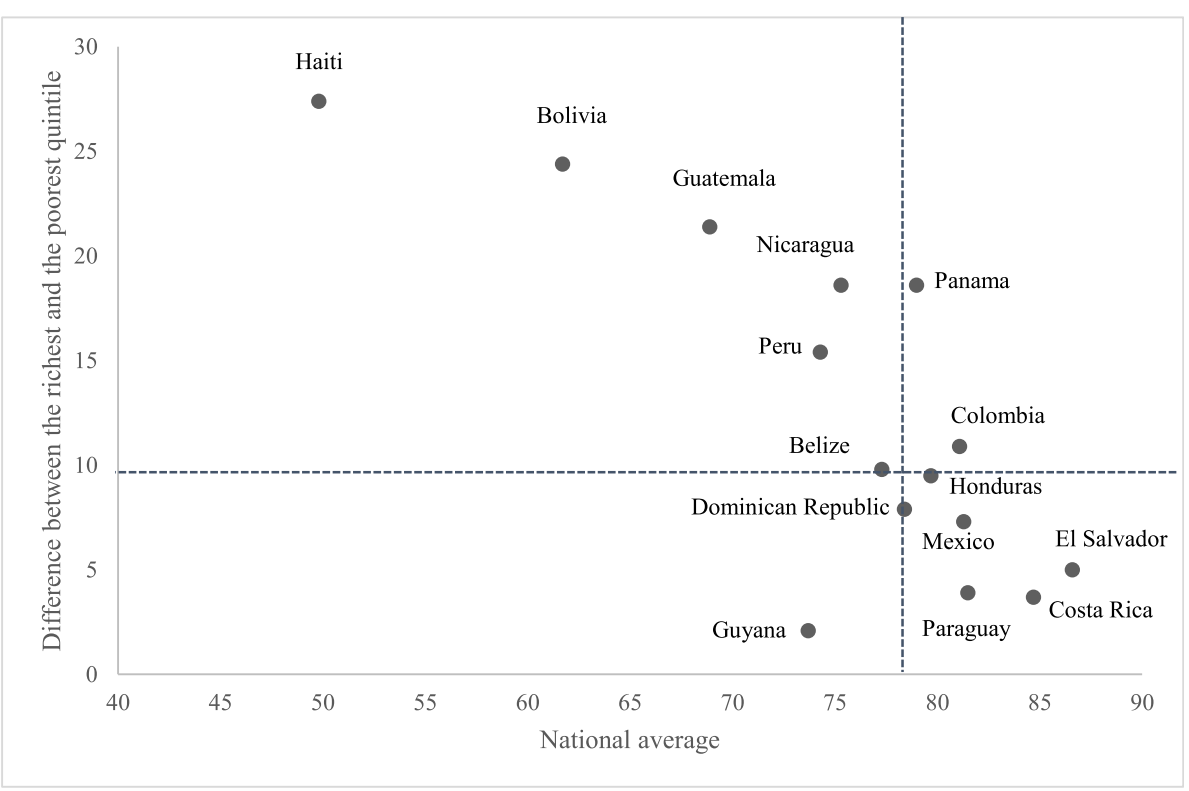

Source: Own elaboration based on study data.

${ }^{\text {a }}$ Dashed lines indicate the median.

Fig. 2 Difference in CCI by country according to wealth quintile, LAC 2001-2016. ${ }^{a}$. Source: Own elaboration based on study data. ${ }^{a}$ Dashed lines indicate the median

households $[7,10]$. Although the countries of the region have indeed implemented reforms to provide health services without the risk of impoverishment, an approach of social determinants and human rights that considers the dimensions of inequality is still required: income, gender, place of residence and education, among others $[21,22]$.

Achieving equity represents a much greater challenge for Colombia, Costa Rica, Haiti, Honduras, Mexico, and Panama than for other countries in the region, since they are part of the ten most unequal countries in the world [23]. If wealth-related inequalities were eliminated, most countries could achieve coverage of $\mathrm{RMNCH}$ interventions of more than $82 \%$. The relationship between $\mathrm{CCI}$ and PAR\% suggests that to reduce the gap in coverage of health services, the implementation of policies and programs can be effective in addressing inequalities within each country [11]. Policies should be focused on five areas: (i) development of health infrastructure; (ii) health promotion; (iii) health human resources; (iv) healthcare financing, and (v) quality of care [24-26].

There is a political commitment to understanding inequalities, encompassing efforts to support the monitoring and evaluation of inequities, health policies, and systems. However, the possibilities of achieving the SDG goals will depend on the ability of countries to accelerate and maximize their achievements in well-being [27]. The study, publication and discussion of the determinants of equity in the coverage of interventions and their impact on health contribute to increases in the effectiveness of public policies [28].

This study has several limitations. Coverage estimates are based on reanalyzed data from demographic surveys with a cross-sectional design. The analysis is limited to the availability of recent surveys in each country for latest situation analysis. Because the ICC is a group indicator, HEAT does not provide sufficient data to estimate the standard error using resampling methods [7]. The household ranking of the wealth index may vary by year and country. The described limitations could underestimate the $\mathrm{CCI}$ in study countries, particularly utilizing an index based on selected $\mathrm{RMNCH}$ health interventions. Despite the limitations, our findings are based on the best method to explore gaps in care coverage between rich and poor [8].

\section{Conclusions}

Overall, our results suggest that women and children from the poorest households in LAC are far from achieving universal health coverage due to inequalities. Our findings show how RMNCH coverage could improve if inequalities were eliminated. Overcoming inequalities will substantially reduce the extreme poverty gap, maternal and child mortality, and promote sustainable development. Future research is needed to monitor inequalities as a critical component tracking the progress 


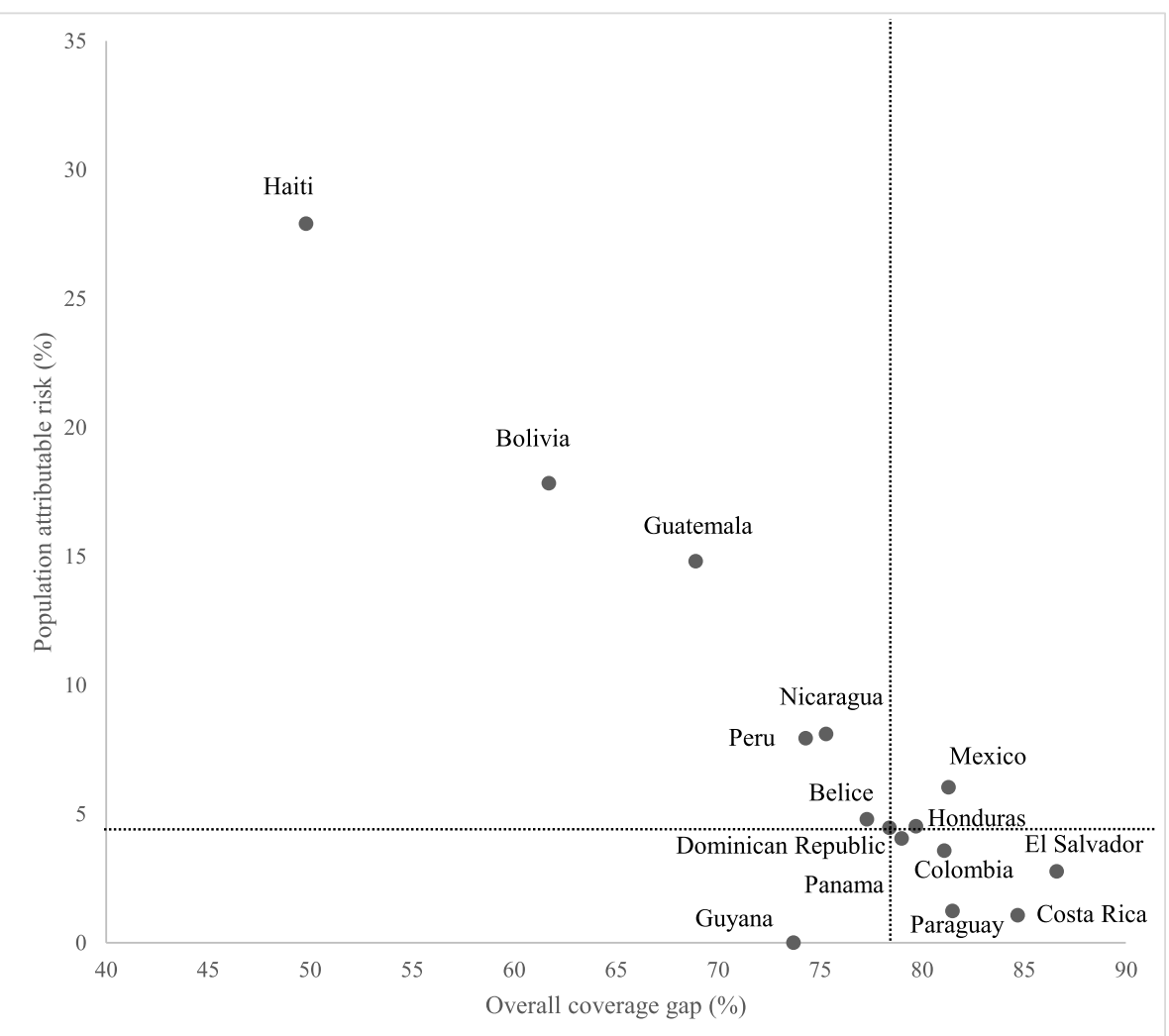

Source: Own elaboration based on study data.

${ }^{a}$ Dashed lines indicate the median.

Fig. 3 Coverage gap at the national level versus population attributable risk in LAC countries, 2001-2016. . Source: Own elaboration based on study data. ${ }^{a}$ Dashed lines indicate the median

of the SDGs so that no one is left behind. We hope that our findings contribute to the design of public policies and strategies to reduce inequalities for women and children in the LAC region.

\section{Supplementary Information}

The online version contains supplementary material available at https:/doi. org/10.1186/s12889-020-10127-3.

Additional file 1: Table S1. Mean coverage of inequality gaps in interventions by wealth quintile, LAC 2001-2016.

\section{Abbreviations}

ALC: Latin America and the Caribbean; ANC4: Prenatal care (at least four visits); BCG: One dose of Bacillus Calmette-Guérin vaccine; CCl: Composite Coverage Index; Cl: Confidence interval; D: Difference; DFPS: Satisfied demand for modern family planning methods; DHS: Demographic Health Survey; DHS: Demographic Health Surveys; DPT: Three or more doses of diphtheria-tetanus-pertussis vaccine; HEAT: Health Equity Assessment Toolkit; MCV: At least one dose of measles vaccine; MDGs: Millennium Development Goals; MICS: Multiple Cluster Indicator Survey; NSCLC: Children with pneumonia symptoms taken to a health center; ORS: Children with diarrhea receiving oral rehydration therapy and continuous feeding; PAR: Population attributable risk; PAR\%: Percentage of population attributable risk; R: Ratio; RD: Ratio for differences: RCl: Relative concentration index: RMNC H: Reproductive, Maternal, Newborn, and Child Health; SBA: Deliveries attended by qualified personnel; SD: Standard deviation; SDGs: Sustainable Development Goals; SII: Slope index of inequality; WHO: World Health Organization

\section{Acknowledgments}

We thank Cesar Matos and Antonio Peramo for comments, suggestions, and language improvement. Special thanks to Carlos Sosa for the statistic notes.

\section{Authors' contributions}

MC conceived and designed the study, carried out the statistical analysis, and drafted the paper; JD and AG analyzed the data, interpreted the results, and contributed to drafting the manuscript. The authors read and approved the final manuscript.

\section{Funding}

The authors declare that there was no funding associated with this study.

\section{Availability of data and materials}

The datasets used in this article are available in the WHO Health Equity Monitor Database repository at http://apps.who.int/gho/data/node.main. HE-1540?lang=en. Individual data sets are available by the previous request and can be accessed by UNICEF http://mics.unicef.org/ and DHS http:// dhsprogram.com/ websites.

Ethics approval and consent to participate

All analyses are based on publicly available data from demographic surveys.

Consent for publication

Not applicable. 


\section{Competing interests}

The authors declare they have no competing interests.

\section{Author details}

'Instituto Tecnológico de Santo Domingo, Universidad Rey Juan Carlos, Madrid, Spain. ${ }^{2}$ Universidad Autónoma de Madrid, Madrid, Spain.

Received: 8 July 2020 Accepted: 23 December 2020

Published online: 10 January 2021

\section{References}

1. Akseer N, Bhatti Z, Rizvi A, Salehi AS, Mashal T, Bhutta ZA. Coverage and inequalities in maternal and child health interventions in Afghanistan. BMC Public Health. 2016;16(Suppl 2):797. https://doi.org/10.1186/s12889-0163406-1.

2. Naciones Unidas. Objetivos de Desarrollo del Milenio. New York; 2015. http://www.un.org/millenniumgoals/2015_MDG_Report/pdf/MDG.2015.rev. (July1).pdf. Accessed 15 May 2020.

3. Bryce J, Black RE, Victora CG. Millennium development goals 4 and 5: progress and challenges. BMC Med. 2013;11:11-4.

4. Comisión Económica para América Latina y el Caribe. América Latina y el Caribe: una mirada al futuro desde los objectivos de desarrollo del milenio: informe regional de monitoreo de los objectivos de desarrollo de milenio (ODM) en América Latina y el Caribe 2015. Santiago; 2015. https:// repositorio.cepal.org/bitstream/handle/11362/38923/S1500709_es.pdf.

5. United Nations. Resolution a/RES/70/1. Transforming our world: the 2030 agenda for sustainable development. New York: Seventieth United Nations General Assembly; 2016. 15 September 2015-13. https://undocs.org/sp/A RES/70/1. [Accessed 25 Apr 2020].

6. Barros AJD, Wehrmeister FC, Ferreira LZ, Vidaletti LP, Hosseinpoor AR, Victora CG. Are the poorest poor being left behind? Estimating global inequalities in reproductive, maternal, newborn and child health. BMJ Glob Health. 2020:5:1-9. https://doi.org/10.1136/bmjgh-2019-002229.

7. Wehrmeister FC, Restrepo-Mendez MC, Franca GVA, Victora CG, Barros AJD Summary indices for monitoring universal coverage in maternal and child health care. Bull World Health Organ. 2016;94:903-12. https://doi.org/10. 2471/BLT.16.173138.

8. Countdown to 2030 Collaboration. Tracking progress towards universal coverage for reproductive, maternal, newborn, and child health. ResearchOnline. 2018;61:27-37.

9. Mujica OJ, Moreno CM. From words to action: measuring health inequalities to "leave no one behind". Pan Am J Public Heal. 2019;43:e12. https://doi. org/10.26633/RPSP.2019.12.

10. Restrepo-Méndez MC, Barros AJD, Requejo J, Durán P, Serpa LAF, França GVA, et al. Progress in reducing inequalities in reproductive, maternal, newborn, and child health in Latin America and the Caribbean: an unfinished agenda. Rev Panam Salud Publica. 2015;38:9-16 https://iris.paho. org/handle/10665.2/10003.

11. Hosseinpoor AR, Victora CG, Bergen N, Barros AJD, Boerma T. Towards universal health coverage: the role of within-country wealth-related inequality in 28 countries in sub-Saharan Africa. Bull World Health Organ. 2011:89:881-90. https://doi.org/10.2471/BLT.11.087536.

12. Marbach M. Mind the gap: equity and trends in coverage of maternal, newborn, and child health services in 54 countdown countries countdown. Res Polit. 2008:5:1259-67. https://doi.org/10.1177/2053168018803239.

13. Health Equity Assessment Toolkit (HEAT). Software for exploring and comparing health inequalities in countries. Built-in database edition. Version 3.1. Geneva: World Health Organization; 2019.

14. World Health Organization. Global Health Observatory data repository. Health equity monitor database; 2019. https://apps.who.int/gho/data/node. main.nHE-1540?lang=en. Accessed 21 Dec 2019.

15. Wehrmeister FC, Barros AJD, Hosseinpoor AR, Boerma T, Victora CG. Measuring universal health coverage in reproductive, maternal, newborn and child health: an update of the composite coverage index; 2020. p. 110. https://doi.org/10.1371/journal.pone.0232350.

16. World Health Organization. Composite coverage index (\%). The Global Health Observatory. https://www.who.int/data/gho/indicator-metadataregistry/imr-details/4489. [Accessed 24 Apr 2020]

17. Rutstein SOJK. The DHS wealth index. DHS comparative reports no. 6. 1st edition. Calverton: ORC Macro; 2004. https://dhsprogram.com/pubs/pdf/ CR6/CR6.pdf.
18. World Health Organization. Techical notes. Reproductive, maternal, newborn and child health (RMNCH) interventions, combined. New York. www.who. int/gho/indicator_registry/en/. Accessed 25 Apr 2020.

19. Schneider M, Castillo-Salgado C, Bacallao J, Loyola E, Mujica O, Vidaurre MRA. Métodos de medición de las desigualdades. Rev Panam Salud Pública. 2002;12:398-415. https://doi.org/10.1186/s12913-018-3766-6.

20. Programa de las Naciones Unidas para el Desarrollo. Más allá del ingreso, más allá de los promedios, más allá del presente: Desigualdades del desarrollo en el siglo XXI. New York; 2019. http://hdr.undp.org/sites/default/ files/hdr_2019_overview___spanish.pdf.

21. Etienne CF. Equidad en los sistemas de salud. Rev Panam Salud Publica/Pan Am J Public Heal. 2013;33:79-82. https://doi.org/10.1590/S102049892013000200001

22. Adegbosin AE, Zhou H, Wang S, Stantic B, Sun J. Systematic review and meta-analysis of the association between dimensions of inequality and a selection of indicators of reproductive, maternal, newborn and child health (RMNCH). J Glob Health. 2019;9:1-13. https://doi.org/10.7189/jogh.09.010429.

23. World Bank. Poverty and shared prosperity: taking on inequality 2016. Washington, D.C: World Bank; 2016.

24. Lassi ZS, Salam RA, Das JK, Bhutta ZA. Essential interventions for maternal, newborn and child health: background and methodology. Reprod Health. 2014;11(Suppl 1):1-7. https://doi.org/10.1186/1742-4755-11-S1-S1.

25. Brizuela V, Tunçalp Ö. Global initiatives in maternal and newborn health. Obstet Med. 2017;10:21-5. https://doi.org/10.1177/1753495X16684987.

26. Bright T, Felix L, Kuper H, Polack S. A systematic review of strategies to increase access to health services among children in low and middle income countries. BMC Health Serv Res. 2017;17:1-19. https://doi.org/10. 1186/s12913-017-2180-9

27. Bhutta ZA, Chopra M. Devolving countdown to countries: using global resources to support regional and national action. BMC Public Health. 2016; 16(Suppl 2):1-2. https://doi.org/10.1186/s12889-016-3400-7

28. Moucheraud C, Owen H, Singh NS, Ng CK, Requejo J, Lawn JE, et al. Countdown to 2015 country case studies: what have we learned about processes and progress towards MDGs 4 and 5? BMC Public Health. 2016;16 Suppl 2. https://doi.org/10.1186/s12889-016-3401-6.

\section{Publisher's Note}

Springer Nature remains neutral with regard to jurisdictional claims in published maps and institutional affiliations.

Ready to submit your research? Choose BMC and benefit from

- fast, convenient online submission

- thorough peer review by experienced researchers in your field

- rapid publication on acceptance

- support for research data, including large and complex data types

- gold Open Access which fosters wider collaboration and increased citations

- maximum visibility for your research: over $100 \mathrm{M}$ website views per year

At BMC, research is always in progress.

Learn more biomedcentral.com/submission 